\title{
Representing the People: British Democracy and Epistocracy in an Age of Political Ignorance
}

Christopher H. Achen \& Larry M. Bartels (2016) Democracy For Realists: Why Elections Do Not Produce Responsive Government (Princeton University Press). Jason Brennan (2016) Against Democracy (Princeton University Press). Ilya Somin (2016) Democracy and Political Ignorance: Why Smaller Government is Smarter, Second Edition (Stanford University Press).

Many citizens know very little about politics (Bennett, 1989; Campbell et al, 1960; Delli-Carpini \& Keeter, 1996; Converse, 1964; Friedman, 2006). Some know less than nothing in the sense that they are actively mistaken about the political world they inhabit (Brennan, 2014; Caplan, 2007). Furthermore, many of those who know the least do not know how little they know: many citizens are systematically mistaken not only about politics, but about how much they know about politics (Dunning et al, 2003). This is a problem. Low levels of political knowledge among citizens can lead to bad governance (Fischer, 2009). And the fact that political knowledge tends to be disproportionately concentrated among the socially and economically privileged can lead, and has led, to an inequality of political influence along the same demographic lines (Caplan, 2007; Gilens, 2014; Gilens \& Page, 2014; Mair, 2013; Parvin, 2015, 2017, 2018; Solt, 2008).

Political ignorance is bad for individuals and bad for societies. It is bad for individuals because it can lead people to vote for policies which harm their interests, or to abstain from beneficial participation. While the impact of each individual's ignorance is low, the combined ignorance of many citizens can have dramatic effects on democratic outcomes and their lives (Brennan, 2016; Somin, 2016). It is bad for societies because it harms others. Democracy allows individuals to exercise power over their fellow citizens, so if voters 'act foolishly, they don't just hurt themselves', they hurt others too (Brennan, 2016; p. 9). Democratic theorists often emphasise the self-regarding nature of democratic participation: participation emancipates individuals through self-government and confirms their equal moral status. However, once we take seriously the fact that voting and other forms of democratic participation are other-regarding acts as well as self-regarding ones, it becomes reasonable to 
consider whether limits might be placed on who can participate, how they participate, and what the right to participate is grounded in, if one even exists.

Jason Brennan's Against Democracy, Ilya Somin's Democracy and Political Ignorance, and Christopher H. Achen \& Larry M. Bartels's Democracy for Realists tackle these and other questions head on. Each is grounded in a unifying observation: the vision of democracy offered by many democrats is so out of kilter with lived reality that we must either radically reorient our understanding of democracy (Achen \& Bartels and Somin) or abandon it (Brennan). What we need, for Achen \& Bartels, is a more 'realistic' approach that acknowledges citizens' limitations. This means accepting that our political preferences are shaped not by reason or deliberation as they are thought to by many liberals, deliberative democrats and epistemic democrats, but by identity-conferring group memberships. For Somin, the solution is to decentralise and reduce the power of elected governments so that citizens can 'vote with their feet', moving around the country to live under laws that suit them. For Brennan it means either incorporating significant epistocratic constraints into existing democratic practices, or rejecting democracy altogether and replacing it with a system which 'distributes political power in proportion to knowledge or competence' (Brennan, 2016, p. 208).

In order to make real progress in understanding and reforming democracy, these authors say, we should put aside our lofty expectations about how we would like citizens to act, what we would like them to know, and what an ideal democracy might look like, and grapple instead with the difficult and unpalatable facts about the way people do act, what they do know, and what a realistically attainable model of democracy might look like. People are subject to cognitive biases (Baron, 2009; Arceneaux, 2012). They possess a tribal mentality which thwarts free thought and hinders the free exchange of reasons and ideas (Haidt, 2012; Westen, 2008). They often do not listen or react in good faith to views alternative to their own or to political or ethical claims which challenge their own (Mutz, 2006). We therefore need to be attentive to the limits of ideal theorising about democracy. In Brennan's words, we need to drop 'semiotic' arguments for democracy and judge it on instrumental grounds. If we do so, he believes, the problems become all too obvious. Democracy places too much power in the hands of individuals who cannot wield it responsibly and who often use it to hurt others (Brennan, 2011). This can lead, and has led, to bad governance, injustice, failures of democratic 
responsiveness, and a concentration of political power among economic elites (Baumgartner et al, 2009).

Numerous political theorists have argued that representative democracy is in crisis and should be replaced (e.g. Landemore, 2017b). In fact, the opposite is true. Many of the systemic problems facing contemporary democracies would be most effectively addressed by an increased emphasis on representation. These three books, in their own ways, offer a guide as to how and why this might be done. The central challenge is not how to encourage wider citizen participation but rather how to enable representative institutions to do their jobs better in a context of widespread political ignorance, unequal political knowledge, and citizen disengagement. A central component of a such a strategy, I suggest, must be to reform representative institutions in order that they might harness the positive benefits to democracy associated with the rise of elite governance. This is a claim that goes against the grain of much contemporary democratic theory, which tends to criticise elitism and seek ways of placing greater control directly in the hands of citizens. I draw on these three works in order to suggest that many of the problems facing democracies in the $21^{\text {st }}$ century might be addressed by relying less on citizens to think and act in ways that they do not or cannot, and by emphasising the role of institutions in representing citizens as well as holding the will of the people in check. I develop this argument in the context of British democracy, which is characterised by two opposing trajectories of democratic reform.

1. Why more democracy is not (always) the answer.

Many democratic theorists and politicians have suggested that the 'remedy for our democratic deficit is to devolve as much power as possible down to the local level' (Tampio, 2017). Indeed, something like this view has informed the vast majority of local government reform in England and Wales over the past two decades. A raft of reforms under New Labour and then the coalition government over this period have seen a significant decentralisation of powers to local institutions and electors. The most high-profile changes include the introduction of elected city, local authority, and 'metro' mayors, and elected Police and Crime Commissioners (PCCs), but other reforms have also been made which have given local communities and other non-state actors greater control over such things as planning 
decisions, the delivery of local services, the ownership of buildings and land, and education (HM Government, 2015; Parvin, 2009 \& 2011).

Introducing more democracy at the local level, and elected mayors and PCCs in particular, was supposed to (a) improve governance, and (b) increase citizen engagement (HM Government, 2010; Gash \& Sims, 2012). Evidence suggests that it has failed on both counts (Electoral Commission, 2013). Firstly, the introduction of elected mayors and police commissioners has not improved governance because failings in governance did not in general stem from the fact that those in charge were unelected, but rather from obstructive relations between the local and the centre (House of Commons, 2009; Walker, 2000). Furthermore, the increased involvement of local citizens in the delivery of public services has not made these services run more effectively or cheaply (Boles, 2013; Rozee, 2014). Local government institutions in England and Wales have faced severe pressures in recent years due to a legacy of underfunding and lack of support. The hope among the drivers of democratisation was that forcing local government leaders to be more accountable to local residents would create incentives to save money and to allocate resources responsibly. It has not (House of Commons, 2016).

Secondly, localist reforms have not increased citizen engagement. Again, take elected mayors and PCCs as an example. Of the ten cities which held referendums on the establishment of elected mayors in 2012 , only one (Bristol) voted in favour, on a turnout of just $24 \%$ of eligible voters (Sandford, 2017). Turnouts in those referendums did not exceed 35\% in any city. Average turnout in mayoral and PCC elections in England and Wales stands at around 30\%, with turnout in the 2012 PCC elections at only 15\% (a figure which includes a record number of spoiled ballots). Moreover, the vast majority of voters were of high socioeconomic status: introducing elected mayors and PCCs only engaged citizens who were already politically-active, entrenching at the local level social, economic, and participatory inequalities that are also evident at the national level (Birch, 2013; Parvin, 2009, 2011, 2017). Moreover, the problem does not seem to stem from a rational rejection of these particular elections by electorates on the grounds that, for example, elected Mayors or PCCs lack power. If this were the case, we would expect support for other localist initiatives to be higher in practice than it is. But initiatives such as giving local people more control over service delivery and 
planning have proven unpopular among the vast majority of citizens, and particularly unpopular among citizens of a low socio-economic status (Sharman, 2014).

In practice, then, the decentralisation of powers away from the centre toward local communities, and the introduction of elected public officials in place of appointees, has failed to solve problems of local governance or re-engage citizens (Electoral Commission, 2013). Strengthening local democracy by decentralising powers to local people and institutions is also problematic at the level of theory: it is driven by the normative assumption that public policy and service provision should be determined by local people rather than by politicians or individuals with particular expertise or experience. This too is problematic, and helps to explain the failure of localism to improve governance. Democracy is an epistemic transformer: it converts certain kinds of epistemic claims into something else. Epistemic democrats see this as democracy's principle strength. Citing Condorcet's Jury Theorem, the 'miracle of aggregation', or 'the wisdom of the many', epistemic democrats point to the capacity of democracy to convert knowledge into power by providing citizens with the relevant opportunities for participation in collective decision-making (Converse, 1964; Estlund, 2009; Landemore, 2017a \& 2017b). Democracy can enable citizens to collectively identify and solve political problems by pooling and discussing their on-the-ground insights and experience.

Brennan, Somin, and Achen \& Bartels criticise epistemic democrats. They point to the literature challenging a fundamental premise of epistemic democracy: that people are 'competent' in the sense that they are more likely to be right than wrong on any particular political issue. But, they say, social science suggests that people are not competent, which leads to collective error and undermines the epistemic value of democracy (Achen \& Bartels, 2016, pp. 40-41; Brennan, 2016, pp. 176-182, \& 2014; Caplan, 2007; Somin, 2016, pp 127-134). Similar concerns about the normative and empirical presuppositions of the Condorcet Jury Theorem and similar mechanisms are widespread enough in the literature to take seriously (e.g. Stanley, 2015). Doing so, however, suggests that we should view democracy's role as an epistemic transformer to be a weakness, not a strength. In circumstances of widespread political ignorance democracy does not convert knowledge into power. It converts opinion into fact, and then converts these facts into power. Opinion is distinct from knowledge. Knowledge is at some level grounded in an acquaintance with the relevant literatures and data; and is gained 
through a generally open-minded process in which individuals test their existing knowledge and assumptions against the best research that can be found. Opinion need not be. It can and does endure in spite of the relevant and best research. Racists, homophobes, mysogynists, and climate change sceptics need not be troubled by evidence which undermines their opinions about gays, women, global warming, or people of colour: their opinions are not grounded in rational evidence or facts, and so cannot be refuted by rational evidence or facts.

Democracy converts opinions into facts, and then facts into power, which is to say: democracy converts opinion into power. This is a problem, and one with which many epistemic democrats continue to struggle (e.g. Goodin \& Spiekermann, 2017; Landemore, 2017a). The fact that a majority of citizens in any given area blame the fact that they cannot get an appointment with their local GP on the number of immigrants clogging up the system does not make it a fact that immigrants are to blame for the long wait for a GP appointment or that (consequently) the situation would be improved by reducing the number of immigrants or denying immigrants the right to see a doctor. Similarly, antisocial 'youths' may not be the highest priority for spending or police time, even if the residents of that area think it is. We know that citizens tend to over-estimate the incidents of certain crimes like burglary, believing that many more burglaries take place in their local area than do in fact take place, and hence that they over-estimate the resources that it is appropriate for the police to devote to resolving this problem. This is also true of other issues too: people get all kinds of things wrong. A recent survey found that UK citizens systematically over-estimate immigration rates, believe that unemployment benefits are more costly to the tax-payer than pensions even though the opposite is true, and that the severity of benefit fraud is twenty-four times worse than it actually is (Ipsos-Mori, 2015).

Once we grasp democracy's role as an epistemic transformer, and also the extent of political ignorance among citizens, a possible explanation for the failure of democratisation to improve governance at the local level is revealed: democratisation places institutions under the control of individuals who do not possess the knowledge to use them in the service of identifying and solving local problems. In societies like Britain and the USA which exhibit low levels of political knowledge among citizens, opinions may run high, while real knowledge about political and other matters is likely 
to be thin on the ground. Hence, in circumstances of the kind we see in Britain and elsewhere, institutions designed to convert knowledge into power often in fact convert baseless assertions and prejudice into facts which are then used to guide government policy. The transformative affect that democracy has on epistemic claims can lead, and has led, to a decline in the instrumental efficacy of democracy as a mechanism for solving political problems or improving the quality of governance.

\section{Embracing elite governance.}

At the same time that local government institutions in England and Wales have given power to elected officials, decision making at the national level has been removed from elected representatives and relocated in non-majoritarian institutions staffed by appointees. Britain affords the unelected House of Lords the power to revise, amend, and delay legislation emanating from the elected House of Commons. Furthermore, Britain, like the USA, increasingly relies on the courts, and judges in particular, to determine the outcome of policy dilemmas by recourse to constitutional law and precedent. Indeed, it is common for legal entities such as the Supreme Courts of the UK and the USA and the European Court of Human Rights to strike down proposed legislation, and to reverse decisions made by elected representatives, on the grounds that they are either unconstitutional or contrary to stipulations contained in wider treaties and formal agreements. Similarly, UK monetary policy is currently set by the Bank of England which (since 1998) has been formally independent of government, and in 2010 the coalition government created the Office of Budgetary Responsibility to provide independent scrutiny and analysis of economic policy. Considerable powers in Britain have been afforded to regulators and other independent public bodies to help develop policy as well as monitor their delivery. Many powers once held by executives and legislatures of the nations of Europe are now held by the institutions of the EU, which are not straightforwardly accountable to the electorates of its member states. And the powers held by international organisations like the International Monetary Fund, the World Bank, the United Nations, and business corporations have also grown.

Trajectories of centralisation at the national level have been widely criticised (e.g. Mair, 2013). They are in part a consequence of global forces, but also of successive governments' desire to incorporate 
private sector and other elite organisations into the formation and delivery of policy at the national level (Bevir, 2010). Contra those who criticise this move, however, the shift toward a more elite system of governance that has been evident at the national level in Britain and elsewhere over the past three decades in fact offers a theoretical and practical response to the concerns outlined in the foregoing section and, in so doing, offers a better hope for effective governance than the opposite approach taken at the local level. Elitism is in part a response by institutions and politicians to the shortfalls in political knowledge caused by low levels of political participation, and also the low levels of information possessed by those citizens who participate. Non-state actors, professionalised lobby organisations, and other extra-political entities act as proxies for citizens. As traditional forms of civil society have declined, grassroots organisations and broad-based political associations have withered, and political participation in the everyday business of democratic life has diminished and become less informed, expert organisations have filled the epistemic space (Putnam, 2001; Skocpol, 2003). Nonmajoritarian organisations have increasingly proven themselves necessary to provide the kind of expertise that democratic states rely on to identify and resolve complex problems and ensure good governance (Parvin, 2015, 2017, 2018; Skocpol, 2003).

The fact that political reform in Britain has been characterised by both a move toward more popular control at the local level and less popular control at the national level provides a useful comparative perspective as regards the likely practical consequences of introducing more direct citizen involvement into national politics, and a possible alternative. The fact that introducing more opportunities for citizens to exert control over local institutions has not improved governance or engaged citizens suggests that doing so at the national level would not improve governance or engage citizens either, especially when we know that the appetite among the public to be involved in national decision making is very low (Hansard Society, 2017). Empirical and normative evidence therefore suggests that we should be wary of making UK democracy more reliant than it currently is on widespread participation, and that we may be better off looking to institutions and representatives to act on citizens' behalf.

Who might these representatives be? Again, at the level of theory, the rise of elite governance has significant democratic potential, as elitists like Schumpeter and democratic pluralists like Robert Dahl 
noted (Dahl, 1961; Schumpeter, 1950). In a society in which the majority of citizens cannot or do not participate in democratic life, in which citizens cannot be relied upon to possess the knowledge necessary for good governance, and in which democracy itself cannot be relied upon to transform relevant knowledge into power, power needs to be exercised elsewhere, by other actors. This is where proxy organisations come in. Citizens' interests can, and are currently, represented by a range of actors at the elite level. Democratic representatives thus include the elected representatives which populate state legislatures, but they also include unelected individuals and groups drawn from a range of proxy organisations. Finding a way to best harness the democratic potentialities of elite governance, and the epistemic contribution to the process of representation that can be made by formally incorporating interest groups and other non-state actors into the process of decision making is a challenge that should be taken up.

One of the most obvious risks associated with adopting a system of democracy in which elite institutions and groups are given more power to represent the people and provide good governance is that private interests will come to dominate decision making as they have in many actually-existing democracies (Baumgartner et al, 2009; Gilens, 2014; Gilens \& Page, 2014). The worsening of social and economic inequality in the USA, for example, has put into doubt Dahl's optimistic vision of a polyarchy in which power is exercised by proxy organisations capable of holding one another in check. As wealth has become increasingly concentrated among those at the very top, so the proxy organisations which advance the interests of the wealthy have become disproportionately powerful relative to those who represent the interests of poor. Meanwhile, political campaigns have become more expensive, and candidates have become increasingly reliant on wealthy donors to fund their efforts to get elected (Bartels, 2016). Structural changes in the fabric of the representative system have thus combined with rising social and economic inequality to ensure that the rich have a disproportionately powerful voice in democracies around the world which they can and do use to entrench their own economic advantage and insulate their wealth in ways not open to poorer citizens (Parvin, 2017; Thomas, 2017).

'Embracing elitism' does not mean allowing social and economic elites to capture the democratic system, or political elites to do whatever they want independently of citizens. It means harnessing the 
power elite of institutions to better represent the interests of citizens, and to work for the common good, within a regime of checks and balances capable of holding these institutions and citizens within reasonable constraints. It requires a system capable of achieving a fair balance between different elites, one which better incorporates knowledge elites, and more effectively holds in check economic ones. Social and economic elites will also sometimes be knowledge elites. Business leaders, for example, will have relevant epistemic contributions to make to debates about certain areas of policy. But we need institutions capable of ensuring that social and economic elites have a seat at the table on account of their epistemic contribution, not simply because of their wealth or status. This is a difficult challenge, and would at least require the establishment of strict laws governing political donations, campaign financing, and political lobbying in order to minimise the impact of money on decision making. But it would also require democratic innovations that enable institutions to discern truth from falsity and represent citizens in ways which are consistent with wider democratic principles of equality and self-government. A great deal of interesting empirical work is being done to determine what form these reforms should take (e.g. Fishkin, 2009; Fung, 2015; Goodin, 2008). One possible approach that I have argued for elsewhere would be the introduction of deliberative mini-publics at the elite level in order to ease the pressure on citizens to think and act collectively at the mass level (Parvin, 2018). Doing so has the potential to sidestep some of the problems associated with political ignorance and cognitive bias identified by Achen \& Bartels in particular. But we might also consider the reform of central institutions in ways which increase opportunities for citizens' voices to be heard, and to make the decision-making process more responsive and transparent. For example, we might, in the UK, strengthen the scrutinising role of select committees and other bodies, and even include citizens' insights - drawn from suitably framed mini-publics - into the business of these committees, in order that appropriate checks might be imposed on the actions of elected governments and, by extension, the popular will. And we might also reform central institutions along more deliberative lines, as suggested by some deliberative democrats (e.g. Dryzek, 2012).

Such initiatives would go some way in plugging epistemic deficits among citizens, by giving them the knowledge and information, as well and the time and space, they need to develop informed views on the issues at hand, while also limiting the power of vested interests to dominate. Others may do so better. However we answer the question of what institutional innovations would best do so, the idea 
that this question - rather than, for example, questions about how we might ensure higher levels of political participation among citizens - should be central to democratic theory would represent an important shift in contemporary democratic theory, especially among many Anglo-American political philosophers for whom declines in citizen participation and certain forms of deliberation have been understood as central (Parvin, 2015). A democratic system characterised by strong representative institutions which are held in check by both appropriate formal institutional checks and balances and which also incorporate citizens' voices in ways which side-step some of the epistemic problems found at the mass level would address the concerns of democrats who emphasise the self-regarding benefits of democracy for individuals, and critics of democracy who emphasise its other-regarding aspects. And it would provide a 'realistic' conception of democracy which can be applied in a world of citizens as they are, not as we might wish them to be.

3. Political Ignorance and the Future of Democracy.

Brennan, Somin, and Achen \& Bartels argue for precisely such a reorientation of democratic theory along more realistic lines. The central problem facing contemporary democracies is not the decline in political participation, they argue, but rather the crisis in the quality of participation that already exists, and the fact that citizens do not form or defend their views in the ways that many democrats often require them to. The problem is the fact of widespread political ignorance among citizens, including those who are politically-active, and that citizens are unlikely to change their minds about political questions as a consequence of reasoned debate with others in the context of mass society (Mutz, 2006).

Why might this be? Achen \& Bartels argue that it is because citizens are more invested in insulating their opinions from criticism than, for example, many liberals and deliberative democrats believe (Achen \& Bartels, 2016; p. 298). The study of democracy should begin with the study of the groups to which individuals belong, and which determine and structure their political preferences, they say. Democratic politics should not be understood as a process of reasoned deliberation but a clash of identities. Doing so reveals that a lot is a stake in political argument. Being forced to change our minds about a political issue might require us to question who we are. Given that doing so can be 
difficult, the rational thing to do is to not engage. Furthermore, for the same reason, it is also rational to not research opposing views too thoroughly, or even to learn too much about the world (Caplan, 2007). If you are a supporter of a political party or movement that believes climate change is a hoax dreamed up by the Chinese government to harm US economic interests, for example, then it is best not to look into the issue too deeply, lest you find some good arguments against your party's position which throw you into crisis. Identity-conferring partisan groups provide a lens through which we might understand ourselves and the world we inhabit, but they also close us off from others who do not share our basic assumptions about life and, hence, do not share a common ground with us over which we might debate complex political questions. This, say Achen \& Bartels, is why debate between partisan members of different political parties is often so unedifying and unproductive. It is also why deliberation at the level of mass society cannot be the answer: democratic politics incentivises citizens to retreat from deliberation rather than seek it out, and cling to opinions rather than subject them to challenge.

Achen \& Bartels do not offer a solution to this problem. Indeed, their only positive suggestion for reform is that states should ensure 'a greater degree of social and economic equality' than we currently see in liberal democratic states (Achen \& Bartels, 2016, p. 325). While this view is not universal among democrats (e.g. Tomasi, 2012), the claim that reducing social and economic inequality is key to reducing political inequality is widely shared (e.g. Birch et al, 2013; Dahl, 1961; Dryzek, 2012; Goodin, 2008; Landemore, 2017a). Nevertheless, the evidence they provide in their book suggests many things that we should not be doing in the interests of enriching democracy, including expecting too much of citizens or of the ability of deliberative reason to deliver consensus on political matters at the mass level.

Brennan argues in more general terms for the replacement of democracy with 'epistocracy', although he leaves open the question of what exactly such a system might look like. Indeed, Brennan's prescriptions appear to vacillate between a radical rejection of democracy to a support of something like Burkhean representation. However, Brennan's central aim is arguably not to defend a specific alternative model of politics, but to clear away what he takes to be the fallacious assumptions about democracy which get in the way of searching for such alternatives. Most importantly, he believes, we 
need to eschew the widely-held view that the right to vote is a signifier of equal moral worth. On this view, removing the right to vote from, say, women or people of colour would be to state that women and people of colour are inferior. We need to drop this way of thinking, he says. After all, we don't think this way about most things and with good reason. We feel that we can deny certain (indeed, most) people the right to perform complicated heart surgery, teach children mathematics, or pilot passenger aircraft, for example, without in doing so making any wider claims about their moral status. Similarly, it should be possible to deny that all citizens should have the ability to vote without thereby denying that all human beings are morally equal. It may be that we don't deny anyone the ability to vote. As Brennan states, a limitation on suffrage is only one (and perhaps not the best) possible strategy of strengthening epistocratic constraints on citizens. But we should at least be able to consider it, he says, without being accused of violating some wider principle of moral equality.

Somin argues for a reduction in the size and scope of the government, and the introduction of a more federal structure in which individuals are able to move around the country in order to live under laws and institutions of their choosing (Somin, 2016; pp. 136 - 181). However, just as Nozick's vision of a libertarian utopia was arguably too optimistic about the ability of the minimal state to ensure citizens a meaningful right of exit from their communities, and as Chandran Kukathas's Hayekian theory of multicultural toleration suffered from the same thing, so Somin's vision of a 'footfall democracy' appears to overestimate the ability of the libertarian state to enable people to leave their chosen communities to join others (Kukathas, 2003; Nozick, 1974).

So there are problems with the solutions that these authors offer. However, their principal strengths lie in describing persuasively the need for solutions. They offer an explanation as to why reform is necessary. Furthermore, although they do not set out to do so, they also offer a guide as to how citizens' insights might be incorporated into democratic processes through, for example, minipublics, in ways which strengthen representation but which are less vulnerable to political ignorance.

Which brings us, finally, to the question of what form of politics is required by the fact of widespread political ignorance among citizens, and how radically different it needs to be from the forms of politics we already have. Brennan, in particular, thinks his argument for epistocracy is radical, as do many of 
his supporters and critics. Even in a post-Trump, post-Brexit world in which fears about political ignorance run high, the claim that democracy is fundamentally flawed because it affords too much power to people too lacking in relevant knowledge to wield it appropriately remains, for many, hard to swallow. But, as I outlined in section 2, the epistocratisation of democracies has been ongoing for many years. Epistocracy seems controversial until we realise that democratic states have always had epistocratic constraints on the will of the people built into them at the ground level, and that the institutions charged with the responsibility of imposing these checks have, at least in Britain, increased in size and strength over the past half century. Representative democracies are, as Manin put it, 'mixed' systems incorporating democratic and non-democratic elements (Manin, 2010). The question is not whether we think that it is important that democracies possess the capacity to overturn the expressed political will of the citizenry. The vast majority of all but the most radical democrats have argued that they should, and that majoritarian institutions should be held in check by, for example, constitutional principles which are in turn policed by courts and other countervailing powers. Mechanisms such as the separation of powers and formal institutional checks and balances exist to ensure that no branch of government - including those populated by elected representatives - should dominate the political process. The question is rather: how much power should these institutions have, and how should we appropriately balance the powers held by these bodies with the powers held by elected representatives, and the people more widely?

Both democracy and epistocracy are matters of degree. Brennan is most explicit in this, but we see it in Somin's work too. Brennan is right that critics of epistocracy often criticise an extreme caricature of the position (e.g. Landemore, 2017a). There are many possible ways in which we might distribute power more effectively among those who have relevant knowledge or experience, or structure our politics in ways which provide this knowledge in appropriate and manageable ways. Indeed, I have argued in favour of such constraints, as well as greater opportunities for citizen involvement in ways which have the potential to resolve problems of political ignorance and cognitive biases, in this essay. Brennan is correct in suggesting that epistocratic checks on democratic decision making can be defended in less extreme terms than many of its critics suggest. However, democracy can also be defended in less extreme ways than Brennan suggests. That is, it is not always clear that Brennan is as fair to democracy in his critique as he would like people to be about epistocracy. Full epistocracy 
by 'simulated oracle' and fully direct democracy exist at opposite ends of a spectrum. Once we understand this, it becomes clear that the task at hand is not to choose between the options at either end, but rather to decide where on the spectrum we should rest.

Once we take seriously the numerous ways in which epistocratic constraints are already present in democratic states, and are attentive too to the fact that many states are at the national level moving away from increased democratisation and toward greater elitism and epistocratic control, then much of the heat and light in the debate between democrats and epistocrats goes away. The ordinary, everyday business of decision making in liberal democratic states around the world is constrained and shaped by institutional checks which are hardwired into the system at the ground level and operate independently of electoral politics. This is why we should consider embracing the increased powers of non-majoritarian organisations and is why we should seek to incorporate citizens' voices into the democratic system in different ways, and at different points in the process, in order that the epistemic deficits evident among the citizenry at a mass level are side-stepped and transcended.

Strengthening representative institutions at the same time as introducing structured opportunities for citizen participation in the business of these institutions would enrich democracy and provide a dual check on the influence of political ignorance and the power of institutions. Retaining universal suffrage, for example, and seeking to incorporate citizens' voices at different points in the representative system via mini-publics would help to empower citizens and ease the pressure on mass publics to think and act in ways that they cannot. It would provide people with the confidence and the knowledge to participate in ways that democracies require and, in providing new opportunities for structured citizen participation, would relax the burden on more conventional forms of participation like voting which have traditionally been required to do all the formal work of converting citizens preferences into policy decisions. Meanwhile, affording increased powers to non-majoritarian institutions at the local, national, and international levels would ensure appropriate constraints on the popular will by strengthening scrutiny and oversight in ways consistent with wider democratic principles. 
This dual approach introduces epistocratic constraints, as well as citizens, at the peripheries and the core of the democratic system. Indeed, the incorporation of mini-publics and other such targeted mechanisms of citizen involvement enables citizens to become more effective epistocratic constraints on the wider popular will. Any proposed legislation would need to stand up to the scrutiny provided by strengthened non-majoritarian institutions and citizens who had been apprised of the facts and given the requisite time and space to form their own informed opinions. Furthermore, suitably structured mini-publics change the incentive structure governing citizens' political behaviour. At the level of the mass public, citizens have the incentive to dismiss the views of others and to ignore evidence that threatens their own views (Achen \& Bartels, 2016). But in a suitably structured discussion, held under supportive and managed conditions, citizens will be required to engage with one another, and to learn the facts of the matter. The incentive in such a forum will be to reach consensus not, as it is in wider mass society, to perpetuate entrenched differences.

Such a strategy would not be straightforward, or without its own weaknesses. The complexity of contemporary governance, and also of the problems states face in the $21^{\text {st }}$ Century, exert pressure on institutional reforms to deliver in difficult circumstances. The sheer volume of information needed to govern effectively in the contemporary context, in which policy dilemmas often transcend demarcated policy areas, jurisdictions, and national borders, and in which decision making is disaggregated across multiple institutions involving multiple actors, poses significant challenges to the conduct of politics on the national and international stages. So many institutions and individuals are involved in the process of making political decisions that it is often difficult to determine where ultimate power lies and, hence, where reforms are most urgent. The point is that these are the questions that we need to be asking. How might we strike a better balance between representation and participation, or between elite decision making and the popular will? How might citizens' concerns be better incorporated into the decision making process given that the problems of political ignorance, cognitive bias, and disengagement make the traditional 'citizen-centred' approach problematic? And how might the impact of these problems be diminished in ways commensurate with wider principles of freedom and equality? A strengthened system of representative institutions which seeks to constrain the public will, but which also seeks to educate and incorporate citizens through limited and focused mini-publics, 
could be reasonably expected to encourage a more honest and open dialogue with citizens about certain facts about the world and about what politics can and should seek to achieve.

Bibliography

Arceneaux, K. (2012) 'Cognitive Biases and the Strength of Political Arguments', American Journal of Political Science 56/2, pp. 271-285.

Baron, J. (2009) 'Cognitive Biases in Moral Judgements That Affect Political Behaviour', Synthese 172/1, pp. 7-35.

Baumgartner, F. R. et al (2009) Lobbying and Policy Change: Who Wins, Who Loses, and Why (Chicago, IL: University of Chicago Press).

Bennett, S. E. (1989) 'Trends in Americans' Political Information, 1967-87', American Political Quarterly 17, pp. 422-435.

Bevir, M. (2010) Democratic Governance (Princeton, NJ: Princeton University Press).

Birch, S. (2013) Divided Democracy: Political Inequality in the UK and Why it Matters (London: IPPR).

Boles, N. (2013) quoted in 'Government Handling of UK Housing Shortage to the Reviewed', The Guardian, Wednesday $20^{\text {th }}$ November. Available: http://bit.ly/2ywOZzm. Accessed: 20th October 2017.

Brennan, J. (2014) 'How Smart is Democracy? You Can't Answer That a Priori', Critical Review 26/12, pp. 33-58. (2011) The Ethics of Voting (Princeton, NJ: Princeton University Press).

Campbell, A. et al (1960) The American Voter (New York: John Wiley \& Sons).

Caplan, B. (2007) The Myth of the Rational Voter: Why Democracies Choose Bad Policies (Princeton, NJ: Princeton University Press).

Converse, P. E. (1964) 'The Nature of Belief Systems in Mass Publics', in D. E. Apter (ed) Ideology and Discontent (London: Free Press of Glencoe).

Dahl, R. (1961) Who Governs? Democracy and Power in an American City (New Haven, CT: Yale University Press).

Delli-Carpini, M.D. \& S. Keeter (1996) What Americans Know About Politics and Why It Matters (New Haven, CT: Yale University Press). 
Dryzek, J. (2012) Foundations and Frontiers of Deliberative Governance (Oxford: Oxford University Press).

Dunning, D. et al (2003) 'Why People Fail to Recognise Their Own Incompetence', Current Directions in Psychological Science 12, pp. 83-121.

Electoral Commission (2013) Police and Crime Commissioners Elections in England and Wales (London: Electoral Commission).

Estlund, D. (2009) Democratic Authority: A Philosophical Framework (Princeton, NJ: Princeton University Press).

Fischer, F. (2009) Democracy and Expertise: Re-Orienting Policy Inquiry (Oxford: Oxford University Press).

Fishkin, J. (2009) When the People Speak: Deliberative Democracy and Public Consultation (Oxford: Oxford University Press).

Friedman, J. (2006) 'Democratic Competence in Normative and Positive Theory: Neglected Implications of "The Nature of Belief Systems in Mass Publics"' Critical Review 18, pp. i-xlii.

Fung, A. (2015) 'Putting the Public Back into Governance: The Challenges of Citizen Participation and its Future,' Public Administration Review 25, pp. 1-10

Gash, T. \& S. Sims eds. (2012) What Can Elected Mayors Do For Our Cities? (London: Institute for Government).

Gilens, M. (2014) Affluence \& Influence: Economic Inequality and Political Power in America (Princeton, NJ: Princeton University Press).

Gilens, M. \& B. I. Page (2014) 'Testing Theories of American politics: Elites, Interest Groups, and Average Citizens', Perspectives on Politics 12/3, pp. 564-581.

Goodin, R. (2008) Innovating Democracy: Democratic Theory and Practice After the Deliberative Turn (Oxford: Oxford University Press).

Goodin, R. \& K. Spiekermann (2017, advance manuscript) A Theory of Epistemic Democracy (Oxford: Oxford University Press, forthcoming).

Haidt, J. (2012) The Righteous Mind: Why Good People are Divided by Politics and Religion (New York: Pantheon).

Hansard Society (2017) Audit of Political Engagement 14 (London: Hansard Society).

H.M. Government (2010) The Coalition: Our Programme for Government (London: Cabinet Office). 
House of Commons (2016) Cities and Local Growth (London: House of Commons Committee of Public Accounts).

Ipsos-Mori (2015) http://bit.ly/2yVYSqW.

Kukathas, C. (2003) The Liberal Archipelago: A Theory of Diversity and Freedom (Oxford: Oxford University Press).

Landemore, H. (2017a) Democratic Reason: Politics, Collective Intelligence, and the Rule of the Many (Princeton, NJ: Princeton University Press).

(2017b) 'Deliberative Democracy as Open: Not (Just) Representative Democracy', Daedalus 146/3, pp. 1-13.

Manin, B. (2010) Principles of Representative Government (Cambridge: Cambridge University Press). Mair, P. (2013) Ruling the Void: The Hollowing of Western Democracy (London: Verso).

Mutz, D. (2006) Hearing the Other Side: Deliberative vs. Participatory Democracy (Cambridge: Cambridge University Press).

Nozick, R. (1974) Anarchy, State, and Utopia (New York: Basic Books).

Parvin, P. (2009) 'Against localism: Does de-centralising power to communities fail minorities?', The Political Quarterly 80/3. (2011) 'Localism and the left: The need for strong central government', Renewal 19/2. (2015) Is Deliberative Democracy Feasible? Political Disengagement and Trust in Liberal Democratic States', The Monist 98/4. (2016) 'Silencing the Critics: Charities, Lobbyists, and the Government's Quiet War on Dissent', Renewal 24/3. (2017) 'Democracy, Capital, and the Rise of the New Inequality' Political Theory 45/6. (forthcoming, 2018) ‘Democracy Without Participation: A New Politics for a Disengaged Era', Res Publica.

Putnam, R. D. (2001) Bowling Alone: The Collapse and Revival of American Community (New York: Simon \& Schuster).

Rozee, L. (2014) 'A New Vision for Planning: There Must Be a Better Way?', Planning Theory and Practice 15/1, pp. 124-138.

Schumpeter, J. (1950) Capitalism, Socialism, and Democracy, $3^{\text {rd }}$ Ed. (New York: Harper Colophon Books). 
Sharman, L. (2014) 'Localism More Popular in Affluent South, Report Finds', LocalGov, $20^{\text {th }}$ March. Available: http://bit.ly/2BBgGWG. Accessed: 30th November, 2017.

Skocpol, T. (2003) Diminished Democracy: From Membership to Management in American Civic Life (Norman, OK: University of Oklahoma Press).

Smith, E. (1989) The Unchanging American Voter (Berkeley: University of California Press).

Solt, F. (2008) 'Economic Inequality and Democratic Political Engagement', American Journal of Political Science 52/1, pp. $48-60$.

Stanley, J. (2015) How Propaganda Works (Princeton, NJ: Princeton University Press).

Tampio, N. (2017) 'Treat People Like Citizens', Aeon: https://aeon.co/essays/why-rule-by-the-peopleis-better-than-rule-by-the-experts. Accessed: 20th October 2017.

Walker, D. (2000) Living With Ambiguity: The Relationship Between Central and Local Government (London: Joseph Rowntree Foundation).

Westen, D. (2008) The Political Brain: The Role of Emotion in Deciding the Fate of the Nation (New York: Perseus Books). 